\title{
EFFECT OF DIETARY REPLACEMENT OF SOYBEAN MEAL PROTEIN WITH COTTON SEED MEAL PROTEIN ON BIOCHEMICAL AND HISTOLOGICAL FEATURES OF NILE TILAPIA MUSCLE
}

\author{
D. M.S.D. El-Saidy ${ }^{1}$, Seham A. Ibrahim ${ }^{2}$, Hanan S.Gaber ${ }^{3}$ and Midhat A. EL- Kasheif ${ }^{3}$
}

1- Department of Poultry Production, Faculty of Agriculture, University of Minufiya, Shebin ElKom, Egypt., P.O.Box 32516. E.mail: devabelsaidy@yahoo.com, 2- Department of zoology, faculty of science,Benha university, Benha, Egypt, 3- National Institute of Oceanography and Fisheries, Fish Research Station, El-Qanater El-Khayria, Egypt

\section{SUMMARY}

This experiment intended to assess the effect of cottonseed meal (CSM) as a partial and complete replacement of soybean meal on biochemical analysis, histological features, the carcass characteristics and meat quality traits of Nile tilapia (Oreochromis niloticus) after 22 weeks of feeding period. Fish with an average initial body weight of $46.4 \pm 1.8 \mathrm{~g}$ were stocked in $15 \mathrm{glass}$ aquarium (90 L each) of 20 fish each. CSM was incorporated at levels of 0, 25, 50, 75, and 100\% with soybean meal protein. Diets were fed to fish twice daily at a rate of $3 \%$ of body weight during 22 weeks the experimental period. The results of the present study revealed that groups of fish fed diet containing 50\% CSM had significant highest final weight (189 g/fish), body weight gain percent (297.2\%), carcass weight (96 $\mathrm{g}$ fish $\left.^{-1}\right)$, fillet weight (49.0 $\left.\mathrm{g} \mathrm{fish}^{-1}\right)$ and dressing \% (50.5\%) compared with fish fed control and other diets. The lowest values of final body weight, body weight gain percent, carcass weight, fillet weight and dressing \% were significantly obtained with fish fed diet containing 100\% CSM. Biochemical analysis of muscles indicated that the maximum dry matter, crude protein crude lipid and ash contents were obtained with groups of fish fed on the diet containing 50\% CSM, while the lowest values were obtained with groups of fish fed on the diet containing 100\% CSM. Fish fed control diet and 50\% CSM diet had significantly the highest values of water holding capacity (W.H.C.), 7.41 and 7.18, respectively, compared with others. The muscles showed histological alterations in fish included degeneration in muscle bundles accompanied with fat vacuole in muscle bundles. Splitting of muscle fibers and atrophy of muscle bundles were seen with increasing CSM concentration more than 50\%. Therefore, these findings suggest that up to 50\% of soybean meal protein can be replaced by cotton seed meal protein in Nile tilapia diets without any adverse effects on biochemical analysis, histological features, the carcass characteristics and meat quality traits of Nile tilapia.

\section{Keywords: Nile tilapia, cotton seed meal, biochemical parameters, histology muscles}

\section{INTRODUCTION}

Recently in Egypt, there is an increase in the production and consumption of freshwater fish reared in aquaculture systems, mainly the Nile tilapia, Oreochromis niloticus. The Nile tilapia, an important farmed fish produced in various parts of the world, very much sought by its low fat meat, shows a growing consumption in Egypt. Brown (1983) reported that tilapia are omnivorous fish which naturally feed on plankton, diatoms, small crustacea, higher plants, and decomposing vegetable matter. Historically, they have been utilized to recycle wastes into high quality fish flesh. They are capable of digesting high levels of carbohydrate in their diet (National Research Council, NRC, 1993), and effectively utilize alternative feed ingredients such as ricebran, cocoa, various flours, Soya, nut oil, and milling wastes (Brown, 1983).

Cottonseed meal has been tested in feeding numerous fish species including tilapia
Sarotherodon mossambicus (Jackson et al., 1982), Nile tilapia, Orechromis niloticus (Rinchard et al., 2000, Mbahinzireki et al., 2001 and El-Saidy and Amal, 2011) and channel catfish, Ictalurus punctatus (Robinson and Li, 1994 and Robinson and Tiersch, 1995). From nutritional point of view, cottonseed meal contains high levels of protein (Forster \& Calhoun, 1995) and is very palatable to fish (Robinson and Li, 1993).

Traditionally, undecorticated cottonseed is crushed and screw-pressed, providing proteinrich crude oilcake that is characterized by high fiber and protein contents. In recent years, additional extraction procedures (fat, protein) deliver a dry cottonseed meal of potentially better quality (Lynn and Wedegaertner, 1986). Due to their high protein content of up to $40 \%$ (Ramachandran et al., 2007), cottonseed products - oilcake and meal - could be used as an inexpensive protein source in fish feeds. However, gossypol, a secondary metabolite stored in the pigment glands of cottonseed, is

Issued by The Egyptian Society of Animal Production 
well-known for numerous antinutritional effects that limit its use as an alternative protein source (Rinchard et al., 2003; Yue and Zhou, 2008).

Thus, the replacement of fishmeal with less costly plant feedstuff must be emphasized. However, the presence of ant-nutritional factors and other active biological compounds limit the use of substitutes, and toxic effects have been reported in fish (Francis et al., 2001; Lee et al., 2006).

The diet of the fish has a great influence on their general chemical composition, and particularly on their fatty acid composition (Henderson and Tocher, 1987). Fillet yield is considered as an important measurement for improving fish production efficiency (Flick et al., 1990). Many works were done to determine the effects of dietary protein levels on fillet yield and chemical composition of Nile tilapia (Oreochromis niloticus) and other fish species (Al-Hafedh, 1999; Li et al., 2001 and Robinson et al., 2007). A possible effect of the quality of the dietary protein source on the biochemical processes during early postmortem stages, with potential consequences on the shelf-life and quality characteristics of the final product was suggested by Parisi et al. (2004).

In tilapia, studies have been conducted to evaluate the effect of low-cost animal and plant protein sources on the fillet yield and meat quality. Therefore, the objective of this study was to investigate the possible different levels of cotton seed meals are used as a partial and complete replacement of soybean meal protein and their effects on biochemical analysis, the carcass characteristics and meat quality traits of Nile tilapia, Comprehensive histopathology of the major organ (muscle) was conducted for adverse gossypol impact.

\section{MATERIALS AND METHODS}

The present work was conducted at the fish research laboratory, Department of Poultry Production, Faculty of Agriculture, Minufiya University ,Egypt. The experiment intended to assess the effect of different levels of cotton seed meal as replacer to soybean protein on the carcass characteristics, meat quality traits biochemical constituent and histology of Nile tilapia (Oreochromis niloticus) muscle after 22 week feeding period.

\section{Diet formulation:}

Reared fish were fed on artificial experimental diets formulated to contain about $32 \%$ crude protein based on feedstuff values reported by National Research Council (NRC), 1993. The control diet $1(0$ cotton seed meal $)$ and four diets (2-5) with $25 \%, 50 \%, 75 \%$, and
$100 \%$ CSM in replacement to soybean meal protein, respectively, were prepared. Animal protein sources (FM) were supplemented in the diets as $3 \%$ of total crude protein. Other dietary ingredients included in the diet were soybean meal, wheat bran, soybean oil, fish oil, vitamin and minerals premixes. Each of the five diets was subjected to proximate analysis using standard methods (AOAC, 2000). The formulation and proximate composition of the dietary ingredients and experimental diets are presented in table (1)

\section{Experimental system and animals:}

About 350 Nile tilapia fish (Oreochromis niloticus) with an average initial weight of 46.4 $\mathrm{g} /$ fish collected from the Nile River at ELKanater EL-Khyria station during April, 2010. Fish were stocked in a concrete pond $\left(40 \mathrm{~m}^{2}\right)$ for two weeks for adaptation before transportation to the fish research laboratory at Department of Poultry Production, Faculty of Agriculture, Minufiya University ,Egypt for experimental initiation. Fifteen glass aquaria each of 120 liter capacity and $60 \times 40 \times 50 \mathrm{~cm}$, dimension were filled with 90 liter dechlorinated tap water. The water in each aquarium was provided with sufficient aeration by means of an electric air compressor. Throughout the experiment, each aquarium was partially cleaned daily and the water was completely changed once a week. At the start of the experiment, five experimental diets, namely from 1 to 5 were assigned each to triplicate groups (each group contained 20 fish in a random manner). Each group of fish was weighed at the beginning and every two weeks throughout the experimental period. Fish were fed six days a week at a rate of $3 \%$ of a body weight during the experimental period. The fish samples were collected from each aquarium before feeding at the end of the experiment (22 weeks).

\section{Carcass characteristics:}

At the end of the experiment fish was immediately weighed to obtain the final body weight (BW). Body weight gain \% was calculated as follows: Final Wt- initial Wt/ initial $\mathrm{Wt} \times 100$. Fins and viscera were removed. The body cavity was washed with tap water to remove any traces of blood. Fish was weighed again to calculate the dressing percentage. Fillet was separated and fillet weight (FW, with skin and ribs) in grams was recorded. Fillet yield was calculated according to Rutten, et al. (2004) as: F \%= (FW/BW) X 100. Fillet samples were divided into two groups, the first group was used after harvest to determine the fillet chemical composition. The second group was stored at $4^{\circ} \mathrm{C}$ for 10 days to determine the effect of dietary 
treatments on fillet quality after this storage period. Fillet samples were minced using a meat mincer, and mixed for the chemical analysis.

\section{Flesh quality traits: \\ Physical properties:}

$\mathrm{pH}$ value was determined in the flesh using the method of Aitken, et al., (1962), Bechman pH meter. Water Holding Capacity (W.H.C.) of fish fillet samples was measured according to the method described by Wierbicki and Deatherage (1958). The sample of $0.3 \mathrm{~g}$ of fillet weight was placed under ashless filter paper (Whatman No. 41) and pressed for 10 minutes using $1 \mathrm{~kg}$ weight. Two zones were formed on the filter paper and measured using planimeter. The water holding capacity was calculated by subtracting the area of the initial zone from that of the outer zone. The data were expressed as $\mathrm{cm}^{2}$.

\section{Chemical composition:}

Percentages of moisture, protein, fat, ash in fillet were determined according AOAC (2000) methods. The crude protein and fat in dry matter of experimental fish were determined using Kjedahl and Soxhlet apparatus. Water content was estimated by maintained the fish muscle at $105^{\circ} \mathrm{C}$ for $24 \mathrm{~h}$.

\section{Histological study:}

At the end of the experiment, 6 fish from each treatment, including the control and muscle samples were fixed in $10 \%$ buffered formalin for histopathological study. Samples were cosseted and processed using auto embedded (Shandon Excelsior, Thermo) examination for dehydration, clearing and wax impregnation. Processed fish tissues were embedded in paraffin wax and sectioned by microtome (Leica 2035 Biocut) set at $5 \mu \mathrm{m}$ thickness. Tissue sections were stained with haematoxylin and eosin and examined under a light microscope (Olympus BX51) to assess any histological changes in the muscle.

\section{Statistical analysis:}

Data were analyzed by analysis of variance (ANOVA) using the SAS ANOVA procedure (Statistical analysis system 1988). Duncan's multiple range test (Duncan 1955) was used to compare differences among individual means. Treatment effect were considered significant at $\mathrm{P} \leq 0.05$. All percentage and ratio were transformed to arcsin values prior to analysis (Zar 1984).

\section{RESULTS}

Initial body weight, final body weight, body weight gain, carcass weight, fillet weight, dressing percentage and fillet percentage are shown in Table (2). Fish fed diet containing $50 \%$ CSM had significant $(\mathrm{p}<0.05)$ the highest final body weight (189 $\left.\mathrm{g} \mathrm{fish}^{-1}\right)$, body weight gain \% (297.2\%), carcass weight (96 g fish $\left.^{-1}\right)$, fillet weight $\left(49.0 \mathrm{~g} \mathrm{fish}^{-1}\right)$ and dressing $\%(50.5 \%)$ compared with fish fed control and other diets. The lowest $(p<0.05)$ values of final body weight, body weight gain percent, carcass weight, fillet weight and dressing \% were significantly obtained with fish fed diet containing $100 \%$ CSM.

\section{Physical properties:}

Water holding capacity (W.H.C.) and $\mathrm{pH}$ values are presented in Table (3). Water holding capacity was identified as the ability of meat to hold its own or added water during the application of any force such as pressing, heating, etc. This phenomenon is one of the more important physical characteristics of meat and fish and mainly affects their texture, as well as is completely related to the proteins quality and quantity. Table 3 indicated that fish fed control diet and 50\% CSM diet had the highest values of water holding capacity (W.H.C.), 7.41 and 7.10, respectively. The results indicated that $\mathrm{pH}$ values of Nile tilapia fillet ranged from 6.3 to 6.5 . No significant differences were observed between the control diet and the other diets in $\mathrm{pH}$ records with different levels of CSM.

\section{Chemical composition:}

Percentages of dry matter, protein, fat and ash contents of Nile tilapia fed the cotton seed meal experimental diets are presented in Table (4). There was a significant $(P<0.001)$ effect of the tested diets on dry matter, crude protein, crude fat and crude ash contents of Nile tilapia muscle. Biochemical analysis of muscles indicated that the highest $(P<0.001)$ values of dry matter, crude protein crude lipid and ash contents were obtained with groups of fish fed on the diet containing $50 \%$ CSM, while the lowest values were obtained with groups of fish fed on the diet containing 100\% CSM. The highest significant crude protein value of $92.14 \%$ was obtained with groups of fish fed diet containing 50\% CSM (Diet 3) compared with other diets. The lowest value of crude protein content (76.51) was obtained with groups of fish fed 100\% CSM (Diet 5). The highest crude lipid content of $4.01 \%$ was obtained with groups of fish fed diet containing $50 \%$ CSM compared with control and other diets.

\section{Histological observation:}

No recognizable changes were observed in the muscle of control group of fish (Fig. 1). The histological alterations in the muscle of 
Nile tilapia fish fed diets containing 25 and $50 \%$ CSM diets 2 \& 3 show fish muscle bundles splitting with edema appear (Fig.2 and 3 ). Muscles of fish fed diet 4 (75\% CSM) show that the fish muscle bundles containing vacuolar degeneration (fat vacuoles) and atrophy of muscle bundles were seen (Fig. 4). Muscles of fish fed diet 5 which contained $100 \%$ CSM show focal areas of necrosis with homogenous liquid appearance and the muscle tissue characterized by disappearance of striations, also an atrophy of nuclei of muscle fibers (Fig.5a and 5b).

\section{DISCUSSION}

The chemical composition of fish muscle varies greatly from one species to another and even among the individuals within the same species. Such variation depends on age, size, sex, environment and season (Huss, 1995); Silva and Chamul, 2000). In fact, the variation in the chemical composition of fish is closely related to feed intake, migratory swimming and sexual changes in connection with spawning (Sallam et al., 2007).

An important intrinsic factor related to fish flesh is the very high post-mortem $\mathrm{pH}(>6.0)$. Most fish contain only very little carbohydrate $(<0.5 \%)$ in the muscle tissue and only small amounts of lactic acid are produced postmortem (Gram and Huss, 1996). In the present study, $\mathrm{pH}$ values of Nile tilapia fillet ranged from 6.3 to 6.5. Control diet had higher $\mathrm{pH}$ values (6.5) in the fillet compared to $75 \%$ and $100 \%$ CSM diets which had pH value of 6.3 . No significant differences were observed between the control diet and the other diets. $\mathrm{pH}$ is related to the post-mortem evolution of the flesh and is influenced by the species, feeding, station of the year, etc.( Periago et al., 2005)

Water holding capacity was identified as the ability of meat to hold its own or added water during the application of any force such as pressing, heating, etc. Fish fed control and $50 \%$ CSM diets had significantly the highest values of W.H.C, values were 7.41 and 7.18, respectively. Regost et al. (2004) verified that Liquid holding capacity (LHC) was increased by dietary soybean oil. No significant differences were detected among 75 and 100\% CSM diets. Sayed et al. (1999) indicated that body fat content of Nile tilapia was lower with increasing soybean meal protein. Results of the present study showed that total lipid contents

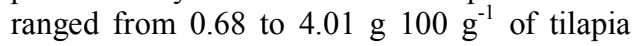
fillet for experimental diets. The highest value of crude lipid content of $4.01 \%$ was obtained with groups of fish fed diet containing 50\% CSM diet 3, while the lowest value was obtained with groups of fish fed 100\% CSM (diet 5). Total lipid contents was increased significantly $(\mathrm{P}<0.05)$ up to $50 \%$ CSM level then decreased with increasing CSM in the diets supplemented with 75 \& 100\% CSM (diets 4 \&5). However, Clement and Lovell (1994) indicated that fat content of Nile tilapia fillet was lower than channel catfish while protein content was higher for tilapia. Meric et al. (2011) found that growth and feed efficiency was reduced when cottonseed meal was used as a replacement of soybean, suggesting the existence of antinutritional factors other than gossypol. This is further supported by the substantially reduced growth performance observed when glandless free cottonseed was used. Feed quality and composition may have contributed to this effect, (Cheng an Hardy, 2002) for rainbow trout fingerlings and Pham et al. (2007) for Japanese flounder. These findings contradicted the earlier report by Jackson et al. (1982) that tilapia grew well on CSM-based protein, even at $100 \%$ level of inclusion.

Winston (2008) indicated that the main oilseed protein sources soybean meal (SBM), Cottonseed meal (CSM) and Groundnut cake (GNC) could replace at least $50 \%$ of fish meal protein in the diet of $O$. niloticus fingerlings, without adversely affecting growth and feed efficiency which agree with the results obtained in the present study. Zheng et al. (2011) regarded that, supplementation and protein reduction had no effect on the viscerosomatic index of fish or moisture, lipid, and protein content of muscle samples.

Unfortunately, few studies have been concerned with histological effects of cottonseed meal (CSM) on muscle of $O$. niloticus, the effects detected in histological alteration of the muscle tissues are important in relation to the health of tilapia that depend on CSM as dietary protein source. The histological alterations in the muscles of studied fish included degeneration in muscle bundles accompanied with focal areas of necrosis and vacuolar degeneration, atrophy of muscle bundles, splitting of muscle fibers. In addition muscle tissue characterized by disappearance of striation was seen in groups of fish which fed diets containing more than $75 \%$ CSM level. This result emphasized high significant increase in water holding capacity result. In conclusion, the findings suggest that up to $50 \%$ of soybean meal protein can be replaced by cotton seed meal protein in Nile tilapia diets without any adverse effects on biochemical analysis, histological features, the carcass characteristics and meat quality traits of Nile tilapia. 


\section{ACKNOWLEDGMENTS}

The financial support provided by the Minufiya University College of Agriculture, Shebin El-Kom, Egypt, for our fish research laboratory is greatly acknowledged.

\section{REFRENCES}

Aitken A., Casey J. C., Penny I. F. and C. A. Voyle, 1962. Effect of drying temperature in the accelerated freeze drying of pork. Journal Society Food Agriculture; 8: 439442.

Al-Hafedh Y. S. (1999) Effects of dietary protein on growth and body composition of Nile tilapia, Oreochromis niloticus L. Aquaculture Research; 30: 385-393.

AOAC (Association of Official Analytical Chemists) (2000) Association of Official Analytical Chemists. Official Methods of Analysis Association of Agriculture Chemists. Washington, DC. USA.

Brett, J. R. and T.D.D. Groves, 1979. Physiological energetic P. 279-352. IN: W. S. Hoar, D. J. Randall, and Brett, J. R. (eds.). Fish physiology. Volume 8. Bioenergetic and growth. Academic press, New York

Brown E. E., 1983. World Fish Farming: Cultivation and Economics. 2nd edn. AVI Publishing, Westport, CT, 397 pp.

Cheng Z.J. and R.W. Hardy, 2002. Apparent digestibility coefficients and nutritional value of cottonseed meal for rainbow trout (Oncorhynchus mykiss). Aquaculture; 212:361-372

Clement S. and R.T. Lovell, 1994. Comparison of processing yield and nutrient composition of cultured Nile tilapia (Oreochromis niloticus) and channel catfish (Ictalurus punctatus). Aquaculture; 119: 299-310.

Deyab M S D El-Saidy and Amal S. Saad (2011) Effects of partial and complete replacement of soybean meal with cottonseed meal on growth, feed utilization and haematological indexes for mono-sexmale Nile tilapia, Oreochromis niloticus (L.) fingerlings. Aquaculture Research,42:351-359

Duncan, D. B., 1955. Multiple range and multiple F tests: Biometrics; 11: 1-42.

Flick G. J., Barua M. A. and L. G. Enriquez, 1990. Processing finfish. In: Martin, R.E., Flick, G.J. (Eds.), the Seafood Industry. Van Nostrand Reinhold, New York, 117173

Forster L. A. and M.C. Calhoun, 1995. Nutrient values for cottonseed product deserve new look. Feedstuffs; 67: 1-5.
Francis G., Makkar H.P.S. and K. Becker, 2001. Antinutritional factors present in plant-derived alternate fish feed ingredients and their effects in fish. Aquaculture; 199 : 197-227.

Gram L. and H.H. Huss, 1996. Microbiological spoilage of fish and fish products. International Journal of Food Microbiology; 33: 121-137.

Henderson R. J. and D.R. Tocher, 1987. The lipid composition and biochemistry of freshwater fish. Progress Lipid Research; 26: 281-347.

Huss H. H., 1995. Quality and quality changes in fresh fish. FAO Fisheries Technical Paper No. 348, Food and Agriculture Organization (FAO) of the United Nations, Rome, Italy.

Jackson A.J., Capper B.S. and A.J. Matty, 1982. Evaluation of some plant proteins in complete diets for the tilapia Sarotherodon mossambicus. Aquaculture; 27: 97-109.

Lee K.J., Rinchard J., Dabrowski K., Babiak I., Ottobre J.S. and J. E. Christensen, 2006. Long-term effects of dietary cottonseed meal on growth and reproductive performance of rainbow trout: three-year study. Animal Feed Science Technology; 126: $93-106$

Li M. H., Manning B. B., Robinson E. H. and B.G. Bosworth, 2001. Effect of dietary protein concentration on growth and processing yield of channel catfish, Ictalurus punctatus, raised from advanced fingerlings to large marketable size. Journal of Applied Aquaculture. Food Products Press, Binghamton; 11: (4), 49-56.

Luo L., XueM.,Wu X., Cai X., CaoH. And Y. Liang, 2006. Partial or total replacement of fish meal by solvent-extracted cottonseed meal in diets for juvenile rainbow trout(Oncorhynchus mykiss). Aquaculture Nutrition ;12: 418-424.

Lynn A. and T.C. Wedegaertner, 1986. Advances in feeding cottonseed products. pp. 195-200. In: A.R. Baldwin (ed.). World Conference on Emerging Technologies in the Fats and Oils Industry. American Oil Chemists Society.

Mbahinzireki G.B., Dabrowski K., El-Saidy D. and E.R.Wisner, 2001. Growth, feed utilization, and body composition of tilapia (Oreochromis sp.) fed cottonseed mealsbased diets in a recirculating system. Aquaculture Nutrition; 7:189-200.

Meric I., Wuertz S., Kloas W., Wibbelt G. and C. Schulz, 2011. Cottonseed Oilcake as a Protein Source in Feeds for Juvenile Tilapia (Oreochromis niloticus): Antinutritional Effects and Potential Detoxification by Iron Supplementation. 
The Israeli Journal of Aquaculture Bamidgeh IIC; 63: 588-595.

NRC (National Research Council) (1993) Nutrient requirements of warm water fishes and shellfishes, National Academy of Sciences, Washington, DC, USA.

Parisi G., Francesco M., Medale F., Scappini F., Mecatti M., Kaushik S. J. and B.M. Poli, 2004. Effect of total replacement of dietary fish meal by plant protein sources on early postmortem changes in the biochemical and physical parameters of rainbow trout. Veterinary Research Communications. Kluwer Academic Publishers, Dordrecht, Netherlands; 28: (1), 237-240.

Periago, M.J.; Ayala, M.D.; Lo' pez-Albors, O.; Abdel, I.; Martı'nez, C.; Garci'aAlca'zar, A.; Ros, G.and F. Gil, 2005. Muscle cellularity and flesh quality of wild and farmed sea bass,

Dicentrarchus labrax L. Aquaculture; 249 : 175- 188

Pham M.A., Lee K.-J., Lim S.-J. and K.H. Park, 2007. Evaluation of cottonseed and soybean meal as partial replacement for fishmeal in diets for juvenile Japanese flounder Paralichthys olivaceus. Fisheries Science; 73 (4):760-769.

Ramachandran S., Singh S.K., Larroche C., Soccol C.R. and A. Pandey, 2007. Oil cakes and their biotechnological applications - A review. Bioresearchs Technology; 98 : 2000-2009.

Regost C., Jakobsen J. V. andA.M.B. Rørå, 2004. Flesh quality of raw and smoked fillets of Atlantic salmon as influenced by dietary oil sources and frozen storage. Food Research International ;37 (3): 259-271.

Rinchard J., Lee K.J., Dabrowski K., Ciereszko A., Blom J. H . and J.S.Ottobre, 2003. Influence of gossypol from dietary cottonseed meal on haematology, reproductive steroids and tissue gossypol enantiomer concentrations in male rainbow trout (Oncorhynchus mykiss). Aquaculture Nutrition; 9: 275-282.

Rinchard, J., Mbahinzireki G., Dabrowski K., Lee K. J. , Garcia-Abiado M. A and J.S. Ottobre, 2000. Effects of partial or total substitution of fish protein with cottonseed meal in diets on reproductive parameters of tilapia sp Oreochromis.niloticus. Aquaculture America; 2(5): 282.

Robinson E. H. and M.H. Li, 1993. Use of cottonseed meal in aquaculture feeds. In: Lim, C. and Sessa, D. J. (Eds.), Nutrition and Utilization Technology in Aquaculture. AOCS Press, Champaign II, 157-165

Robinson E. H. and M.H. Li, 1994. Use of plant proteins in catfish feeds: replacement of fish meal with soybean meal and cottonseed meal. Journal World Aquatic Society; 25: 271-276.

Robinson E. H. and T.R. Tiersch, 1995. Effects of long-term feeding of cottonseed meal on growth, testis development, and sperm motility of male channel catfish lctalurus punctatus brood fish. . Journal World Aquatic Society; 26: 426-431.

Robinson E. H., Li M. H. H., Manning B. B., Mischke C. C., Sallam Kh. I., Ahmed A. M., Elgazzar M. M. and E.A. Eldaly, 2007. Chemical quality and sensory attributes of marinated Pacific saury (Cololabis saira) during vacuum-packaged storage at $4{ }^{\circ} \mathrm{C}$. Food Chemistry; 102: 1061-1070.

Rutten M. J. M., Bovenhuis $\mathrm{H}$. and $\mathrm{H}$. Komena, 2004. Modeling fillet traits based on body measurements in three Nile tilapia strains (Oreochromis niloticus L.). Aquaculture; 241: 113-122.

Sayed A. N., Abdel-Raheem H., Shoeib H. K. and S.S. Tawfeic, 1999. Evaluation of soybean and cottonseed meal's protein as a substitute for animal protein in tilapia diets. Assiut Veterinary Medical Journal; 40: 80, 222-241.

Silva J. L. and R.S. Chamul, 2000. Composition of marine and freshwater finfish and shellfish species and their products. In R. E. Martin, E. P. Carter, G. J. Flick, Jr., \& L.M. Davis (Eds.), Marine and freshwater products handbook. USA: Technomic Publishing Company, Inc., 3146.

Sallam, K.I., A.M. Ahmed, M.M. Elgazzar and E.A. Eldaly, 2007. Chemical quality and sensory attributes of marinated pacific saury (Cololabis saira) during vacuumpackaged storage at $4^{\circ} \mathrm{C}$. Food Chem.; 102: 1061-1070.

Soltan M. A., 2005. Partial and total replacement of soybean meal by raw and heat treated linseed meal in tilapia, Diets. Egyptian Journal Nutrition and Feeds; 8(1): 1091-1109.

Statistical Analysis System(SAS) (1988) SAS / STAT user's guide release 6.03 edition. SAS Institute Inc. Cary, North Carolina, USA.

Wierbicki E. and F.E. Deatherage, 1958. Determination of water holding capacity of fresh meats. Journal. Agriculture and food Chemistry; 6: 387.

Winston A. N., 2008. Oil seed meals as dietary protein sources for juvenile Nile Tilapia(Oreochromis niloticus L.) M. Sc. Water bioresources and aquaculture. Institute of aquaculture university of stirling Scotland.

Yue Y. R. and Q.C. Zhou, 2008. Effect of replacing Soybean meal with cottonseed meal on growth, feed utilization and 
haematological indexes for juvenile hybrid tilapia.Oreochromis niloticus $\times$ Oreochromis aureus. Aquaculture; 284: 185-189.

Zar J. H.,1984. Bio-statistical Analysis, 2nd edition. Prentice-Hall International, Inc. Englewood Cliffs, New Jersey, USA.

Zheng Z. L., Wang K. Y., Delbert M., Galtin III. And J.M. Ye, 2011. Evaluation of the
Ability of GroBiotic $^{\circledR}-A$ to Enhance Growth, Muscle Composition, Immune Responses, and Resistance Against Aeromonas hydrophila in Nile tilapia, Oreochromis niloticus. Journal World Aquaculture Society; 42: 549-557.

Table 1. Formulation and proximate analysis of the experimental diets ( $\mathrm{g} \mathrm{kg}^{-1} \mathrm{dry}$ matter).

\begin{tabular}{|c|c|c|c|c|c|}
\hline Experimental diets & $\begin{array}{l}1 \text { Control } \\
\text { (0 CSM) }\end{array}$ & $\begin{array}{l}2 \\
(25 \% \mathrm{CSM})\end{array}$ & $\begin{array}{l}3 \\
(50 \% \mathrm{CSM})\end{array}$ & $\begin{array}{l}4 \\
(75 \% \mathrm{CSM})\end{array}$ & $\begin{array}{l}5 \\
(100 \% \mathrm{CSM})\end{array}$ \\
\hline \multicolumn{6}{|l|}{ Ingredients: } \\
\hline Soybean meal & 550 & 412.5 & 275.0 & 137.5 & 0.0 \\
\hline Cotton seed oil & 0.0 & 137.5 & 275.0 & 412.5 & 550.0 \\
\hline Fish meal & 50.0 & 50.0 & 50.0 & 50.0 & 50.0 \\
\hline Wheat bran & 330.0 & 330.0 & 330.0 & 330.0 & 330.0 \\
\hline Fish oil & 15.0 & 15.0 & 15.0 & 15.0 & 15.0 \\
\hline Soybean oil & 15.0 & 15.0 & 15.0 & 15.0 & 15.0 \\
\hline Di-calcium phosphate & 15.0 & 15.0 & 15.0 & 15.0 & 15.0 \\
\hline vitamin mixture & 12.0 & 12.0 & 12.0 & 12.0 & 12.0 \\
\hline Mineral mixture ${ }^{b}$ & 5.0 & 5.0 & 5.0 & 5.0 & 5.0 \\
\hline Lysine & 0.0 & 1.2 & 2.4 & 3.6 & 4.8 \\
\hline Chromium oxide & 0.5 & 0.5 & 0.5 & 0.5 & 0.5 \\
\hline Cellulose & 7.5 & 6.3 & 5.1 & 3.9 & 2.7 \\
\hline \multicolumn{6}{|l|}{ Proximate composition ${ }^{\mathrm{c}}$ : } \\
\hline Dry matter & 891.2 & 887.1 & 887.5 & 890.8 & 889.6 \\
\hline crude protein & 318.2 & 317.8 & 317.6 & 317.5 & 317.3 \\
\hline crude lipid & 35.6 & 37.2 & 37.9 & 38.7 & 40.7 \\
\hline crude fibre & 52.2 & 52.8 & 51.4 & 58.2 & 58.5 \\
\hline Ash & 61.1 & 60.3 & 66.1 & 63.7 & 65.1 \\
\hline $\mathrm{NFE}^{\mathrm{d}}$ & 424.1 & 419.0 & 414.5 & 412.7 & 408.0 \\
\hline Phosphorus & 9.2 & 9.6 & 11.4 & 11.1 & 12.3 \\
\hline Free gossypol ${ }^{\mathrm{e}}\left(\mathrm{mg} \mathrm{kg}^{-1}\right)$ & 0.0 & 11.42 & 22.85 & 34.27 & 45.69 \\
\hline Met. Energy ${ }^{\mathrm{f}}\left(\mathrm{KJg}^{-1}\right.$ feed $)$ & 13.0 & 13.0 & 13.0 & 13.0 & 13.0 \\
\hline \multirow{4}{*}{\multicolumn{6}{|c|}{ 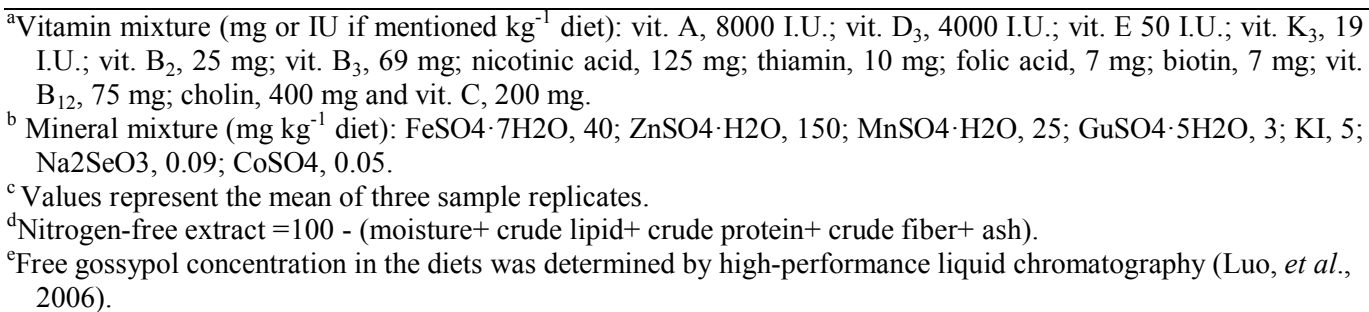 }} \\
\hline & & & & & \\
\hline & & & & & \\
\hline & & & & & \\
\hline \multicolumn{6}{|c|}{$\begin{array}{l}{ }^{\mathrm{f}} \text { Metabolizable energy was calculated based on the standard physiological values of } 18.8 \mathrm{~kJ} \mathrm{~g}^{-1} \text { protein, } 13.8 \mathrm{~kJ} \mathrm{~g}^{-1} \\
\text { carbohydrate, and } 33.5 \mathrm{~kJ} \mathrm{~g}^{-1} \text { fat (Brett \& Groves 1979). }\end{array}$} \\
\hline
\end{tabular}


Table 2. Averages initial body, final body, carcass, fillet, dressing \% and fillet $\%$ of Nile tilapia Oreochromis niloticus fed diets of different levels of CSM. Values are mean ${ }^{1} \pm$ SD.

\begin{tabular}{lccccccc}
\hline \multicolumn{1}{c}{ Diets } & $\begin{array}{c}\text { Initial } \\
\text { Body } \\
\text { Weight } \\
(\mathrm{g})\end{array}$ & $\begin{array}{c}\text { Final } \\
\text { Body } \\
\text { Weigh } \\
(\mathrm{g})\end{array}$ & $\begin{array}{c}\text { Body } \\
\text { Weight } \\
\text { Gain } \\
(\%)\end{array}$ & $\begin{array}{c}\text { Carcass } \\
\text { weight } \\
(\mathrm{g})\end{array}$ & $\begin{array}{c}\text { Fillet } \\
\text { weight } \\
(\mathrm{g})\end{array}$ & $\begin{array}{c}\text { Dressing } \\
(\%)\end{array}$ & $\begin{array}{c}\text { Fillet } \\
(\%)\end{array}$ \\
\hline $1(0 \mathrm{CSM})$ & $45.3 \pm 1.8$ & $122.2 \pm 3.5^{\mathrm{c}}$ & $169.6 \pm 5.6^{\mathrm{c}}$ & $52.2 \pm 2.0^{\mathrm{c}}$ & $33.0 \pm 2.4^{\mathrm{c}}$ & $43.0 \pm 2.0^{\mathrm{b}}$ & $25.0 \pm 1.1$ \\
$2(25 \% \mathrm{CSM})$ & $47.0 \pm 1.8$ & $129.0 \pm 2.4^{\mathrm{b}}$ & $174.7 \pm 7.0^{\mathrm{bc}}$ & $54.2 \pm 1.7^{\mathrm{c}}$ & $31.0 \pm 2.2^{\mathrm{c}}$ & $43.2 \pm 2.0^{\mathrm{b}}$ & $26.0 \pm 1.3$ \\
$3(50 \% \mathrm{CSM})$ & $47.7 \pm 2.2$ & $189.0 \pm 1.8^{\mathrm{a}}$ & $297.2 \pm 17.8^{\mathrm{a}}$ & $96.0 \pm 1.5^{\mathrm{a}}$ & $49.0 \pm 1.7^{\mathrm{a}}$ & $50.5 \pm 1.5^{\mathrm{a}}$ & $27.0 \pm 1.1$ \\
$4(75 \% \mathrm{CSM})$ & $46.0 \pm 0.9$ & $131.0 \pm 1.7^{\mathrm{b}}$ & $185.1 \pm 11.4^{\mathrm{b}}$ & $64.0 \pm 1.5^{\mathrm{b}}$ & $39.0 \pm 2.5^{\mathrm{b}}$ & $45.0 \pm 2.8^{\mathrm{b}}$ & $25.0 \pm 1.8$ \\
$5(100 \% \mathrm{CSM})$ & $46.0 \pm 1.8$ & $115.7 \pm 1.6^{\mathrm{d}}$ & $151.7 \pm 7.4^{\mathrm{d}}$ & $42.7 \pm 1.6^{\mathrm{d}}$ & $27.5 \pm 2.5^{\mathrm{d}}$ & $40.5 \pm 1.4^{\mathrm{c}}$ & $25.0 \pm 2.1$ \\
\hline
\end{tabular}

Table 3. Water holding capacity (WHC) expressed as $\mathrm{cm}^{2}$ and $\mathrm{pH}$ values of Nile tilapia (Oreochromis niloticus) muscles fed CSM diets. Values are mean ${ }^{1} \pm \mathrm{SD}$.

\begin{tabular}{lcc}
\hline Diets & W.H.C & pH \\
\hline $1($ Control 0\%) & $7.41 \pm 0.01^{\mathrm{a}}$ & 6.5 \\
$2(25 \%$ CSM) & $6.19 \pm 0.02^{\mathrm{b}}$ & 6.4 \\
$3(50 \%$ CSM $)$ & $7.18 \pm 0.14^{\mathrm{a}}$ & 6.4 \\
$4(75 \%$ CSM $)$ & $5.79 \pm 0.20^{\mathrm{c}}$ & 6.3 \\
$5(100 \%$ CSM $)$ & $5.72 \pm 0.05^{\mathrm{c}}$ & 6.3 \\
\hline
\end{tabular}

${ }^{1}$ Values in the same columns with different superscripts are significantly different $(\mathrm{P} \leq 0.01)$. Values represent the mean of three replicate groups

Table 4. Percentages of dry matter, protein, fat and ash content of Nile tilapia (Oreochromis niloticus) muscle fed diets with different levels of cotton seed meal (CSM). Values are $\operatorname{mean}^{1} \pm$ SD

\begin{tabular}{lcccc}
\hline Diets & Dry matter & Crude protein & Crude lipid & Ash \\
\hline $1($ Control 0\%) & $22.75 \pm 0.59^{\mathrm{b}}$ & $89.88 \pm 1.03^{\mathrm{b}}$ & $1.46 \pm 0.30^{\mathrm{c}}$ & $5.29 \pm 0.28^{\mathrm{d}}$ \\
$\mathrm{r}(25 \%$ CSM $)$ & $22.01 \pm 0.54^{\mathrm{c}}$ & $88.27 \pm 0.99^{\mathrm{b}}$ & $2.14 \pm 0.24^{\mathrm{b}}$ & $6.33 \pm 0.19^{\mathrm{b}}$ \\
$3(50 \%$ CSM $)$ & $24.18 \pm 0.30^{\mathrm{a}}$ & $92.14 \pm 2.23^{\mathrm{a}}$ & $4.01 \pm 0.40^{\mathrm{a}}$ & $7.24 \pm 0.14^{\mathrm{a}}$ \\
$4(75 \%$ CSM $)$ & $23.59 \pm 1.29^{\mathrm{ab}}$ & $81.37 \pm 1.14^{\mathrm{c}}$ & $1.31 \pm 0.07^{\mathrm{c}}$ & $6.65 \pm 0.34^{\mathrm{b}}$ \\
$5(100 \%$ CSM $)$ & $21.01 \pm 0.90^{\mathrm{c}}$ & $76.51 \pm 1.05^{\mathrm{d}}$ & $0.68 \pm 0.20^{\mathrm{d}}$ & $5.66 \pm 0.40^{\mathrm{c}}$ \\
\hline Talues in the same columns with different superscripts are significantly different $(\mathrm{P} \leq 0.01)$. Values \\
represent the mean of three replicate groups.
\end{tabular}




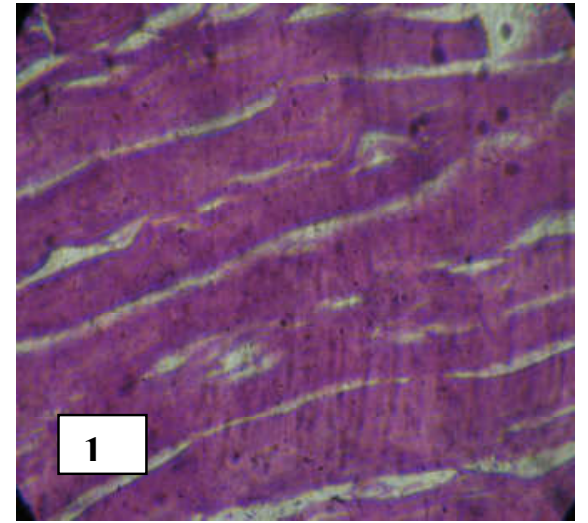

Figure 1. Muscle tissue of fish fed control diet1 showing striation of muscle tissues (X100).

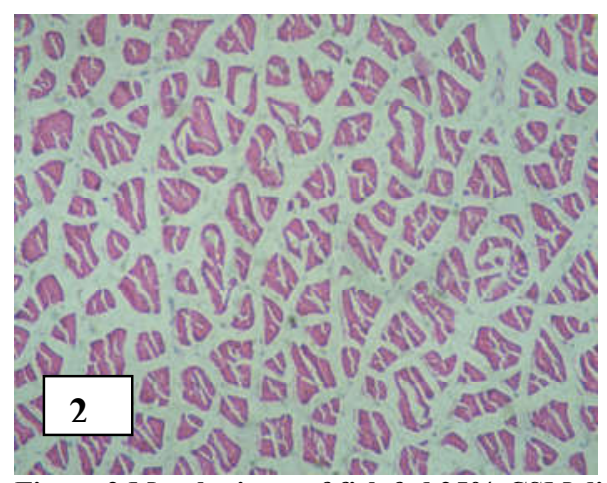

Figure 2.Muscle tissue of fish fed $25 \%$ CSM diet2 diet 5 showing edema and splitting muscle bundle (X100).

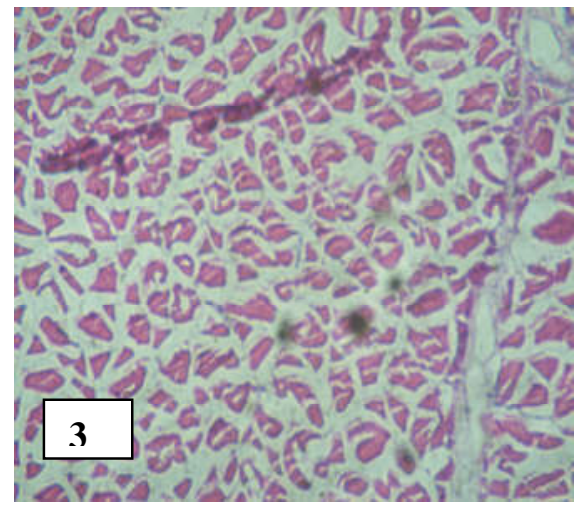

Figure 3. Muscle tissue of fish fed 50\% CSM diet 3 showing atrophy and vacuolar degeneration of muscle bundles (X100).

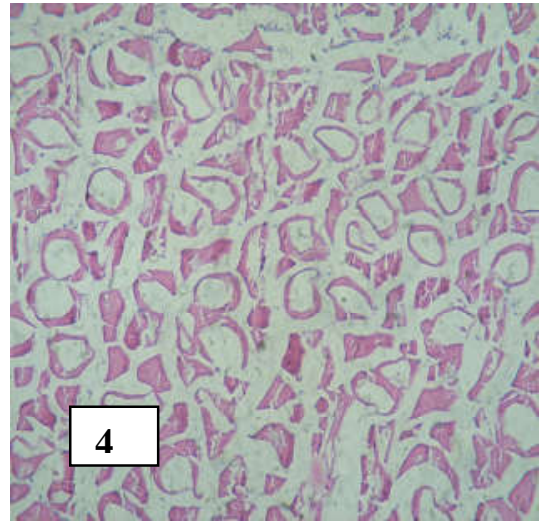

Figure 4. Muscle tissue of fish fed $75 \%$ CSM diet 4 showing splitting muscle tissue (X100).

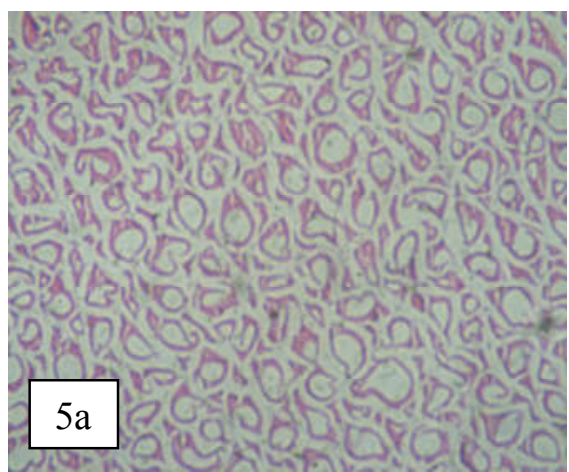

Figure 5a. Muscle tissue of fish fed $100 \%$ CSM showing vacuolar degeneration of muscle bundle (X100).

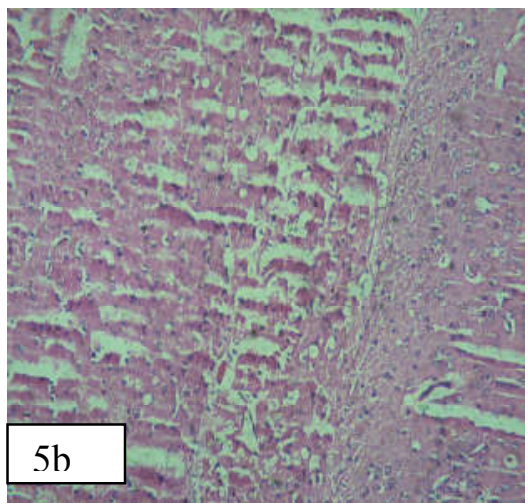

Figure 5b. Muscle tissue of fish fed100\% CSM diet 5 showing disappearance of striation of muscle tissues (X100). 


\section{أثر إحلال بروتين كسب فول الصويا بيروتين كسب بذرة القطن فى علائق أسماكك البلطى النيلى على مكونـات

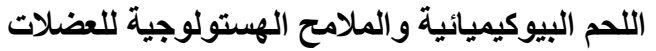

دياب محمد سعد دياب الصعيدى', سهام أحمد ابراهيم” ,حنان سيد جابر "، مدحت عبد الفتاح الكاشف؟ ا ـقسم إنتاج الدواجن، كلية الزنراعة بشبين الكوم، جامعة الدنوفية، مصر r - ـ قسم علم الديوان، كلية العلوم، جامعة بنها، مصر،

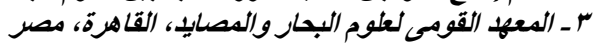

أجريت هذة التجربة لدر اسة تأثير اضافة بروتين كسب بذرة القطن كبديل جزئى أو كلى لبروتين كسب فول الصويا في البـ العلائق

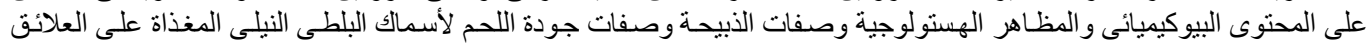

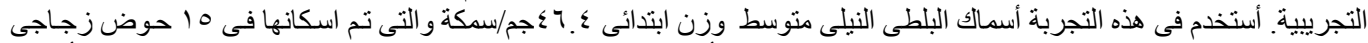

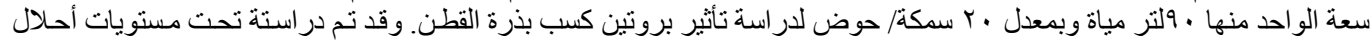

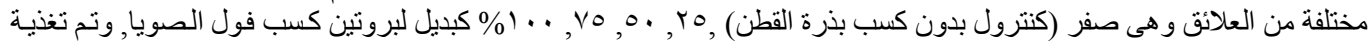

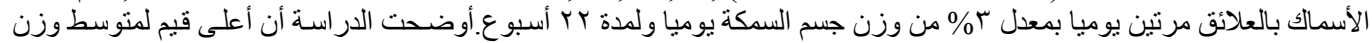

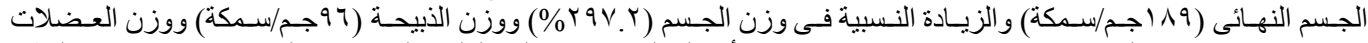

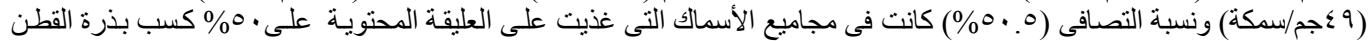

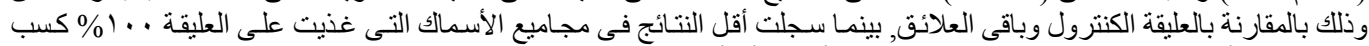

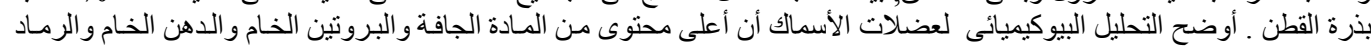

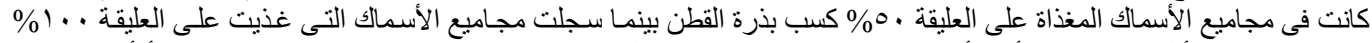

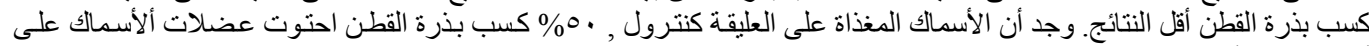

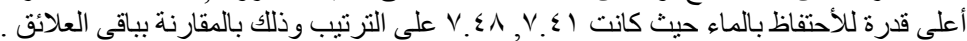

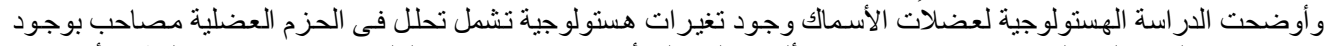

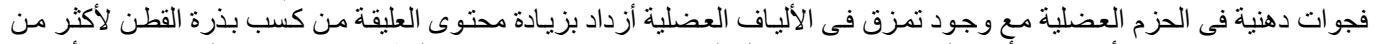

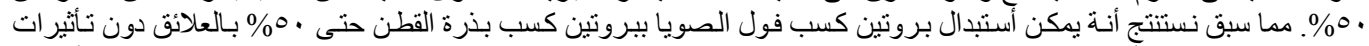

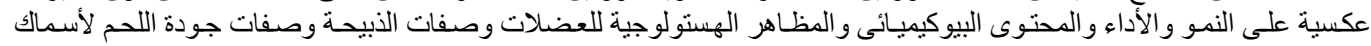
البلطى النيلى. 